\title{
Students' Satisfaction with Online Learning Experiences During the COVID-19 Pandemic
}

\author{
https://doi.org/10.3991/ijet.v15i21.15647 \\ Norah Mansour Almusharraf ${ }^{(凶)}$, Shabir Hussain Khahro \\ Sultan University, Riyadh, Saudi Arabia \\ nmusharraf@psu.edu.sa
}

\begin{abstract}
This research aims to evaluate the level of postsecondary student satisfaction with online learning platforms and learning experiences during the novel coronavirus COVID-19 pandemic in the Kingdom of Saudi Arabia (KSA). This paper is based on transformative learning theories [1], which describe the learners' authority and investment over their learning. Quantitative research was carried out using a survey sent out to 283 students enrolled at one higher education institution in KSA. These data were analyzed using SPSS. Average Mean Score (AMS) was used for data analysis, where the results are validated using the Standard Deviation (SD), Skewness and Kurtosis test, and Cronbach Alpha test. The research findings revealed that the students are satisfied with the university staff and faculty members who agreed on specific online platforms to use, grading system, assessment options, training workshops, online technical support, and more. The research findings also showed that participants were highly satisfied with Google Hangouts the most for lecture delivery, followed by Google Classroom and LMS (Moodle) for course management and assessments. With only respect to the students' online learning experiences, the COVID-19 situation within this study context was handled adequately. This study calls for further research into integrating professional development workshops and practical training courses for online learning and teaching to endorse innovative teaching techniques and alternative assessment plans for instructors, learners, administrators, and policymakers.
\end{abstract}

Keywords - COVID-19, higher education, e-learning tools, online teaching strategies, learning strategies, computer-assisted language learning

\section{$1 \quad$ Introduction}

An emergency public health international concern has caused most higher education institutions worldwide to precipitously close in late March 2020 to avoid the spread of the COVID-19 pandemic [2]. Because of these closures, universities were required to use online teaching platforms, regardless of students' and teachers' level of expertise in technological competencies and preparedness [3].

While online teaching is not a new pedagogical method and has been used for many years in various fields, there is still a lack of proficiency in implementing online learning platforms from K-12 to college-level [4]. Specifically, in the Kingdom of 
Saudi Arabia (KSA), online learning and teaching are not widely implemented across the universities nor within the school systems [5],[6],[7]. After the COVID-19 pandemic, university instructors were given limited online options, including live lectures, recorded video lectures, voice-over demonstrations, and picture-in-picture presentations to deliver the rest of their required instruction. With the latest growth in online learning and integrating technology in teaching in KSA, it is indispensable to explore what underpins the students' satisfaction level in online learning settings and provides technical training and proper instructions.

Research has identified numerous critical challenges thought to affect learning within an online environment. Such challenges include instructors' assessments of learners' academic integrity [8],[9], cyberstalking and cyberbullying [10], lack of internet access, low quality of online instructional delivery, cost control, individual in learning [11], lack of professional technological training [3],[4] tool inaccessibility, and technical issues [12]. Additional challenges are related to the instructors' adaptability skills to customize lectures for online learning, learn to monitor students' synchronous or asynchronous collaboration, and design authentic online assessment tools that accompany the transition to the online platforms from face-to-face sessions [13]. Thus, online instruction necessitates various skills, including pedagogical skills, design skills, technical skills, and communication skills. [6] argues that "case studies, story-telling, streamed videos, discussion groups, and bulletin boards" (p.55) are examples of effective communication techniques, and they are the critical foundation of an interactive online environment.

Research has shown approaches to cope with online teaching more efficiently, including metacognitive awareness and multidimensional approaches [14]. These approaches are concerned with managing: behavioral difficulties (e.g., self-regulation, transformation, and maintenance, cognitive views (e.g., learning competence), and emotional difficulties (e.g., engagement and motivation)

A series of recent studies [15],[16],[17] has indicated that most learners perceive customized or personalized video lectures as useful resources that supplemented their learning - these results aid faculty in comprehending how to use video as a guide to learners' development. The inclusion of various technological tools plays a significant role in stimulating the online education environment and encouraging critical thinking in collaborative interaction.

There are limited institutions in the KSA that are entirely online-oriented; the majority are face-to-face classrooms [18]. However, within recent years, there has been increasing integration of technological tools using e-learning systems such as Blackboard and Learning Management System (LMS) [6]. Thus, it is significant to evaluate the fundamental tools employed within the higher education sector. It is also critical to examine the nature and the measures taken in e-learning materials within an educational context, learners' overall perceptions, performances, and the quality of teaching practices.

While public college education in Saudi Arabia is free for all citizens, and there are vast improvements in the higher educational system, there is not a robust tendency to use online platforms as the primary instructional design [5],[6],[7],[34]. There exists a new body of literature on the reported benefits of online learning in KSA. In a survey 
study of sixty-seven undergraduate Saudi learners, he indicated that online education helped EFL learners overcome cultural norms and develop their communication skills [7]. Similarly,[37] stated that students perceive LMS as a

beneficial tool for their learning development. [38] study results also indicated that blackboard formative online assessment aided learners' performance in the final assessment. Most reviewed studies have relied on the importance of promoting autonomous learners [22] to adapt and experience new skills such as social, technical, and interpersonal skills needed in online communications.

Student satisfaction and other course-related perspectives are influenced by the online teaching strategies adopted to respond to COVID-19 in developing online courses. In this study, teaching strategies refer to the communication platforms and activity selections instructors intend to use when teaching online. Further, because of this pandemic's uncertainty, most higher institutes in KSA are planning contingency procedures to resume online teaching for the upcoming semesters for summer and fall of 2020. In this study, the examination is undertaken within online collaborative and synchronous environments. Within this setting, learners are directed to participate independently and collaboratively using specific online platforms. Their collaboration in learning is viewed from a social context [25],[26],[27].

Therefore, this research aims to assess student satisfaction levels on the utilized online methods and approaches during the pandemic to examine the validity of the tools and measures provided to optimize teaching and learning quality during COVID-19. It is also critical to explore the most and the least effective learning methods and approaches. Consequently, this research aims to explore the answer to the following two questions:

1. To what extent are students satisfied with online teaching and learning approaches utilized during COVID-19?

2. During COVID-19, what are the students' perceptions of the most effective employed online teaching platforms in their learning process?

\section{The Literature Review}

\subsection{The theoretical framework}

This paper is based on the premise of transformative learning theories [19],[20],[21], which describe the learner's authority and investment over his or her learning. This theoretical framework fits well with this paper, in which it examines adult English as a Foreign Language (EFL) learners' attitudes and perceptions toward experiential online learning in the sudden transformation of the online environment in KSA. The transformative learning theory, which was first led by [21], is based on the value of personal experience as a central part of the learning process. It proposes that a learner's understanding of the experience creates meaning, which leads to a transformation in behavior, attitude, and views. In transformative learning theories, learners are exposed to challenge tasks to motivate students' thinking. Learners are also encouraged to use 
critical thinking and questioning techniques to measure their understanding of subject matter. It is critical to point out that when transformational learning occurs, learners initiate the learning process [22] to contribute and collaborate to the social environment in eLearning course design. This study is written to add to the literature reviewed on EFL learners' perceptions and transformative performances toward using online learning platforms as mainstay instruction in KSA during the COVID-19 pandemic outbreak.

\subsection{Background of online learning collaboration}

Online Learning Collaboration is derived from Computer-Mediated Communication (CMC) in distance education [23],[24]. In an online learning setting, learners are given specific channels to interact independently and collaboratively between learners and instructors. Thereby supporting collaborative learning in a social context [25],[26],[27]. Within this study, learners were given opportunities to collaborate in Synchronous Computer-Mediated Communication (SCMC) in language learning in which their interaction between two or more learners concurrently transfer through a computer [28]. Collaboration is also measured through learners' actions in planning, evaluating, valuing, and monitoring their own and peer offerings. Collaborative learning can be broadly defined as an instructive method that includes the core of cooperative learning [29],[30]. Within Collaborative learning, groups of learners collaborate to build a project, assess a development, or complete a mission.

Further, collaborative learning within this study adapted technological tools such as the Learning Management System (LMS), Google Classroom, and Google Hangouts that are supported and recommended by the study school context. Most classes in KSA institutions have shifted toward using learning methods such as video conferencing courses, in which they use a computer and communications technology to apprehend each other simultaneously. Within video-conference courses, instructors incorporate exterior materials such as quizzes, activities, and learning sessions [31]. The employment of video-conference permits useful guidelines on various levels of knowledge and cognitive skills of learners and links with the divergent learning styles

[32]. Students' contributions are either determined by the instructor as an individual task or by a peer as group work.

\subsection{Students' perceptions of online learning}

A more comprehensive description of students' perceptions of online learning can be found in [27] study, where learners perceive online collaborative English language learning as a positive and encouraging learning experience, primarily on account of the productive peer-feedback participation in eLearning. Similarly, [33] study results showed that using the three video lecture types improves the students' learning performance. A study by_[34] showed that the online learning environment encourages a positive influence and improves EFL students' writing skills, self-assurance, and power in composing written texts. Further, a study by [35] confirmed that incorporating online video classrooms has a significant influence on EFL students' reading 
intellectual capacity. A parallel pattern of some reviewed studies (e.g., [34][25][35][26][27]) revealed that the interactive social platforms in online collaborative English learning play a significant part in the participants' positive assertiveness and presentations.

The benefits of integrating online environments include developing autonomous learners [22] in which they self-explore and seek information, and assess, transform, and acclimate new skills needed for millennium learners. Further, online asynchronous learning platforms allow learners to access at their own pace. [36] His study further explained that online environments provided intrinsic goal orientation, self-efficacy for learning, and increased performance. [6] argues that "students who utilize e-learning platforms for learning are usually drawn into the subject matter at a deeper level due to the discussions they get involved in" (p. 55). It also reported that such an environment had aided learners with time management and self-efficacy. Specifically, EFL online collaborative activities have positive effects on raising skills such self-awareness, selfregulation that is related to learners' affective and metacognitive [27], learner engagement [26] and classroom engagement [36],[25] especially in a context where English is taught a foreign language (EFL). However, [33] argues that online learning might hinder students' learning progress if quality instruction is absent. [33] indicated that the selection of online activities, readings, materials, and work contributions should be carefully examined to meet with students' expectations and abilities before integration.

\subsection{The coronavirus (COVID-19) impact on students online learning}

The COVID-19 disease occurrence in late 2019 has rapidly progressed into a worldwide pandemic, and various methods are arguing about its diagnosis, cure, and prevention. [39] have described coronavirus (COVID-19) as "one of the major pathogens that primarily targets the human respiratory system." (p. 1) Thus, in early 2020, public and private institutions have declared the shift to Emergency Remote Teaching (ERT) due to its severe infection transmission of person-to-person interaction. Consequently, institutions were shifted to online environments to contribute to the precautions needed to control this epidemic.

COVID-19 has a destructive impact on students learning achievements._[40] in his study of the effect of COVID-19 on the students' performance, their students' grades negatively affected the epidemic, considering that the school academic calendar was brusquely disturbed by the early closure of all institutions in Zambia. A more comprehensive description can be found in_[41] study regarding the influences of (COVID-19/SARS-CoV-2) epidemic outbreaks on worldwide supply chains: China, Europe, North America, and South America. The result of this study revealed that destructive effects were reported, but mainly learners' performance depended on the timing and measure of interruption spread and the school arrangement. These studies' results are in line with [42] regarding Ghanaian learners' negative perspective on the Impact of COVID-19 on their learning. The main issues were related to limited access to the internet and the lack of technical knowledge. On the other hand, [43] examined the influence of COVID-19 impact on students' performance in higher education in 
Universidad Autónoma de Madrid (Spain), revealed that such circumstances developed students' learning approaches, their efficiency, and learning achievement.

SCMC with video-conferencing was utilized in this study as a collaborative learning environment to substitute face-to-face classes in KSA after they were canceled due to the Covid-19 crisis. Thus, a yet unsolved question is whether or not

EFL students' perceptions of online learning are negatively affected by the COVID19 epidemic. A critical inquiry associated with the situation is how learners perceive online teaching platforms as effective platforms in their learning progress?

\section{$3 \quad$ Research Method}

The purpose of this survey study is to explore students' perceptions of online learning delivery, as well as instructors' and school support during the COVID-19 pandemic. It also aims to investigate students' preferred online platforms and methods of learning.

\subsection{The instrument}

The survey utilized in the current study was created by the researchers and was based on information about online learning and teaching from the extant literature and from the experience of the first author, who earned a Ph.D. in Higher Education and involved in teaching EFL postsecondary level in the KSA. Concerning the validity of the instrument [44], the survey was reviewed by three qualified local and international postsecondary instructors with an academic rank of associate professor or higher within the field of education, and with at least three years of experience in online teaching. Content validity was applied when modifications were made to the survey's structure and content to meet their recommendations.

The survey was generated using Google forms using the online platform and through which it was disseminated. The survey was made available to all undergraduate students in May 2020. The first three opening questions within the survey urged the respondents to provide demographic information about themselves. The remaining twenty-two questions required responders to specify their level of agreement to a statement typically in scale ranged from (1) strongly disagree (2) disagree (3) neutral (neither agree nor disagree), (4) agree, (5) strongly agree.

All questions were shaped in a set of online questionnaires and to attain the students' perceptions and satisfaction level on the effectiveness of different actions taken by university management to promote online teaching and learning during the COVID-19 pandemic. The survey was sent to the students via different online portals, including the learning management system (Moodle), Google Forms, social networking apps (WhatsApp and Twitter), and emails. The questionnaire was divided into four sections; student demographic details, students' satisfaction level of the online learning environment, students' satisfaction of the school support, and students' perceptions of the most effective online learning methods and platforms. 


\subsection{Participants}

The total number of participants who responded to the survey was 283 participating students are freshmen, sophomores, juniors, or seniors studying on a part or full-time basis. The participants' ages range from 18-30. Participated students were from various majors including Accounting, Applied Linguistics, Architecture, Aviation Management, Communications \& Networks, Computer Science, Construction Management, Deanship of Educational Services (GSD), Deanship of Educational Services, Finance, Information Systems, Interior Design, Law, Marketing, Production Management, Physical Education, Health and Recreation, Software Engineering, Translation and the University English Program (UEP). All students have passed the university English admission exam before they could register in their chosen academic majors. Some students have taken the IELTS or TOFEL exams to be excused from the preparatory year's English Language curriculum. Therefore, the survey was conducted in English, and no translation was necessary to be added as the items were written in basic English to be easily understood (see Appendix A).

\subsection{The context}

The study was conducted in one private, non-profit institution in Saudi Arabia. The medium instruction is taught in English, and most of the hired staff and faculty members are proficient in the English language. The institution is accredited and licensed by the Ministry of Higher Education. The school has five colleges: College of Law, College of Humanities, College of Engineering, College of Business Administration, and College of Computer \& Information Sciences. The school facilitates a teaching and learning center, e-learning center, and technology information center that facilitates students and faculty to switch on online educational activities.

A condition of conducting this study is to get approval from the university and submit an application to the Institutional Review Board (IRB). The IRB's main objective is to certify the protection of human subjects by reviewing, consenting, modifying, or disapproving research requests submitted by students. This study was reviewed and cleared by the Institutional Review Board (IRB-2020-05-0039). Within the welcome message, survey participants were notified that completion of the survey indicated their consent to participate in this research. No compensation was awarded to any participants who completed the survey.

\section{$4 \quad$ Analysis}

A descriptive statistical analysis of the survey was conducted using the Statistical Package for Social Science (SPSS), version 25. Responses to each question in the survey were imported into SPSS from Google forms, and complete data of 283 respondents for each question was plotted in the SPSS interface. Aggregated Mean Score (AMS) was used as a data analysis approach. The AMS has been successfully used numerous times in such data sets [45],[46],[47]. In the next phase, the result 
validation was a crucial milestone in this research; therefore, a two-tier approach was developed. Standard Deviation (SD) and Skewness \& Kurtosis tests were conducted on the data in tier one. Both validate each question separately as a distinct entity. Whereas in tier two Cronbach Alpha test was conducted to validate the whole result set of this study.

\subsection{Standard deviation}

Standard deviation is a function of how often a range of values differs or disperses. Statisticians have calculated that values no higher than plus or minus $2 \mathrm{SD}$ are measurements closer to the true value than those in the higher than \pm 2 SD region [48].

\subsection{Skewness \& kurtosis}

Skewness is a function of the asymmetry, and kurtosis is a function of a distribution's 'peakedness.' Most quantitative packages send you skew and kurtosis values, as well as standard errors. The values for skewness between -2 and +2 are considered appropriate to prove normal univariate distribution. The kurtosis values between -3 and +3 are deemed appropriate to prove normal univariate distribution [49].

\subsection{Cronbach alpha}

Cronbach's alpha is a measure of internal consistency; that is, how closely related a set of items are as a group. It is considered to be a measure of scale reliability. A reliability coefficient of 0.70 or higher is considered "acceptable" in most social science research situations [50][51].

\section{$5 \quad$ Results}

In the first phases of the questionnaire of this paper, respondent demographic information was collected. Table 1 shows the respondent's age.

Table 1. Respondent Age

\begin{tabular}{|c|c|c|c|c|c|}
\hline \multicolumn{2}{|c|}{} & Frequency & Percent & Valid Percent & Cumulative Percent \\
\hline \multirow{4}{*}{ Valid } & 18 or under & 29 & 10.2 & 10.2 & 10.2 \\
\cline { 2 - 6 } & $19-24$ & 220 & 77.7 & 77.7 & 88.0 \\
\cline { 2 - 6 } & $25-30$ & 34 & 12.0 & 12.0 & 100.0 \\
\cline { 2 - 6 } & Total & 283 & 100.0 & 100.0 & \\
\hline
\end{tabular}

The respondents' age ranged from 18 or under to 30 years old. In this study, participants who reported their age from $19-24$ years are $77.7 \%$ in total. Whereas, the students who reported their age of 18 or under and 25-30 were at smaller percentages. Table 2 shows the respondent gender categorization. 
Table 2. Respondent Gender

\begin{tabular}{|c|l|c|c|c|c|}
\hline \multicolumn{2}{|c|}{} & Frequency & Percent & Valid Percent & Cumulative Percent \\
\hline \multirow{3}{*}{ Valid } & F & 151 & 53.4 & 53.4 & 53.4 \\
\cline { 2 - 6 } & $M$ & 132 & 46.6 & 46.6 & 100.0 \\
\cline { 2 - 6 } & Total & 283 & 100.0 & 100.0 & \\
\hline
\end{tabular}

As per the total data collected for this research, $46.6 \%$ were female students from the women's campus, and a total percentage of 53.4 were male students from the men's campus. Table 3 shows that the average mean score of all the questions incorporated in section two of this study's questionnaire. The table also shows the results of skewness and kurtosis. Both approaches were used to validate this research's results, and their acceptable limits were discussed in the last section. The item questions can be shown in Appendix (A).

Table 3. Results of Section Two (Evaluation)

\begin{tabular}{|l|c|c|c|c|c|c|c|}
\hline \multirow{1}{*}{ Items } & N & M & SD & \multicolumn{2}{c|}{ Skewness } & \multicolumn{2}{c|}{ Kurtosis } \\
\cline { 2 - 7 } & Statistic & Statistic & Statistic & Statistic & Std. Error & Statistic & $\begin{array}{c}\text { Std. } \\
\text { Error }\end{array}$ \\
\hline $\begin{array}{l}\text { I am } \\
\text { satisfied } \\
\text { with the } \\
\text { level of } \\
\text { support. }\end{array}$ & 283 & 3.88 & 1.042 & -.990 & .145 & .369 & .289 \\
\hline $\begin{array}{l}\text { I am } \\
\text { satisfied } \\
\text { with the } \\
\text { faculty } \\
\text { members' } \\
\text { alternative } \\
\text { assessment } \\
\text { plans. }\end{array}$ & 283 & 3.91 & 1.070 & -.995 & .145 & .311 & .289 \\
\hline $\begin{array}{l}\text { I am } \\
\text { satisfied } \\
\text { with the } \\
\text { course } \\
\text { modality in } \\
\text { delivery. }\end{array}$ & 283 & 3.87 & 1.024 & -1.021 & .145 & .596 & .289 \\
\hline $\begin{array}{l}\text { I am } \\
\text { satisfied } \\
\text { with the } \\
\text { online } \\
\text { classes as } \\
\text { they helped } \\
\text { me achieve } \\
\text { the course } \\
\text { learning } \\
\text { outcomes. }\end{array}$ & 283 & 3.90 & 1.057 & -1.034 & .145 & .644 & .289 \\
\hline
\end{tabular}




\begin{tabular}{|l|l|l|l|l|l|l|l|}
\hline $\begin{array}{l}\text { I am } \\
\text { satisfied } \\
\text { with the } \\
\text { instructors' } \\
\text { follow-up. }\end{array}$ & 283 & 3.99 & 1.040 & -1.141 & .145 & .801 & .289 \\
\hline $\begin{array}{l}\text { I am } \\
\text { satisfied } \\
\text { with the } \\
\text { gained } \\
\text { knowledge } \\
\text { and skills. }\end{array}$ & 283 & 3.89 & 1.049 & -.904 & .145 & .203 & .289 \\
\hline $\begin{array}{l}\text { I am } \\
\text { satisfied } \\
\text { with the } \\
\text { course level } \\
\text { of } \\
\text { engagement } \\
\text { engat }\end{array}$ & 283 & 3.90 & 1.045 & -.920 & .145 & .256 & .289 \\
\hline $\begin{array}{l}\text { I am } \\
\text { satisfied } \\
\text { with the } \\
\text { instructors' } \\
\text { various } \\
\text { online } \\
\text { teaching } \\
\text { approaches. }\end{array}$ & 283 & 3.89 & 1.107 & -.935 & .145 & .124 & .289 \\
\hline $\begin{array}{l}\text { I am } \\
\text { satisfied } \\
\text { with how } \\
\text { the } \\
\text { instructor } \\
\text { makes } \\
\text { online } \\
\text { learning. }\end{array}$ & 283 & 3.95 & 1.092 & -1.043 & .145 & .416 & .289 \\
\hline
\end{tabular}

As mentioned earlier, the questionnaire was divided into four sections, and the first section highlighted the EFL students' demographic contribution. In the second section of the questionnaire, the students' satisfaction level with the online learning environment was assessed. It is analyzed that the students are satisfied with the online learning environment during the COVID-19 pandemic. None of the factors had an average mean score below (AMS 3.5/Agree), an acceptance agreement threshold. The students were satisfied with the instructor approaches chosen for the active learning environment in which instructors encourage self-exploring, peer collaborating, and group collaboration.

Regarding answering the first questions: To what extent are students satisfied with online teaching and learning approaches utilized during COVID-19? Students reported (AMS 3.89/Agree) that they were highly satisfied with the selected method, facilitating their learning outcomes of the course's objectives. Furthermore, it was determined that PowerPoint presentations, projects, and active participation opportunities were highly 
effective as course delivery methods during this rapid shift of online teaching during COVID-19. As a first-time experience, the results showed a highly satisfactory achievement of learning outcomes.

Furthermore, participants were satisfied with course engagement activities levels (AMS 3.90/Agree), instructors follow up with students in course activities (AMS

3.99/Agree), assessment plans (AMS 3.91/Agree), instructor support (AMS 3.95/Agree), online lecture delivery (AMS 3.89/Agree), instructor's selection for teaching pedagogies, and course learning outcome achievement (AMS 3.89/Agree). Moreover, the active follow-up of instruction positively impacts the student satisfaction level on online education. It was observed from the data collected that the learners were highly satisfied with the instructor's active follow-up with students. All the mentioned results were validated by standard deviation value, skewness \& kurtosis values because all the values were within acceptability limits.

The Cronbach alpha value of the nine questions of the second section of this study was (0.973), and based on Cronbach alpha theory, a value closer to 1 validates the appropriateness of the results. Therefore, the results of this section were validated by three filters. The first tier was a standard deviation and Skewness and Kurtosis validation tests for the particular question. The second tier was a Cronbach Alpha test for the section.

Table 4. Results of Section Three (Facility Performance)

\begin{tabular}{|l|c|c|c|c|c|c|c|}
\hline & $\mathbf{N}$ & Mean & SD & \multicolumn{2}{|c|}{ Skewness } & \multicolumn{2}{c|}{ Kurtosis } \\
\cline { 2 - 7 } & & & & Statistic & $\begin{array}{c}\text { Etr. } \\
\text { Error }\end{array}$ & Statistic & $\begin{array}{c}\text { Error } \\
\text { Ert }\end{array}$ \\
\hline $\begin{array}{l}\text { I am satisfied with staff responsiveness to } \\
\text { technical support. }\end{array}$ & 283 & 3.64 & 1.009 & -1.012 & .145 & .438 & .289 \\
\hline $\begin{array}{l}\text { I am satisfied with the school counselor } \\
\text { for mental or social support. }\end{array}$ & 283 & 3.53 & 1.046 & -.866 & .145 & .141 & .289 \\
\hline $\begin{array}{l}\text { I am satisfied with my academic advisor } \\
\text { to follow up and support. }\end{array}$ & 283 & 3.66 & 1.034 & -.940 & .145 & .331 & .289 \\
\hline $\begin{array}{l}\text { I am satisfied with the webinars, } \\
\text { seminars, and courses offered. }\end{array}$ & 283 & 3.59 & .987 & -.856 & .145 & .452 & .289 \\
\hline I am satisfied with the school facilities. & 283 & 3.59 & 1.008 & -1.023 & .145 & .598 & .289 \\
\hline
\end{tabular}

In the third section of the questionnaire, the students' satisfaction with the school support during COVID -19 was analyzed. It was observed that all the students of both campuses are satisfied with the support provided by the school in various forms, including IT issues, online class login problems, academic advising, extracurricular activities, mental and social counseling. The school's different units offered various online workshops and seminars to assist and live-up with students throughout the classes during the pandemic. The students were satisfied with school staff support (AMS 3.64/Agree), social support (AMS 3.53/Agree), academic advising (AMS

3.66/Agree), webinars, seminars, and facilities provided by the school (AMS 3.59/ Agree). Nevertheless, this bond between the learner and school can be enhanced in upcoming semesters. 
Further, the Cronbach alpha value of the 5 questions of the third section of this study was (0.947); therefore, this section's results were validated by a standard deviation, Skewness and Kurtosis, and the Cronbach Alpha test for the section.

Table 5. Results of Section Four (Recommendations)

\begin{tabular}{|l|c|c|c|c|c|c|c|}
\hline \multicolumn{1}{|c|}{ Items } & $\mathbf{N}$ & $\mathbf{M}$ & $\mathbf{S D}$ & \multicolumn{2}{c|}{ Skewness } & \multicolumn{2}{c|}{ Kurtosis } \\
\cline { 2 - 8 } & & & & & $\begin{array}{c}\text { Std. } \\
\text { Error }\end{array}$ & Statistic & Error \\
\hline $\begin{array}{l}\text { I recommend learning using ONLY online classes } \\
\text { in the future. }\end{array}$ & 283 & 3.11 & 1.237 & -.085 & .145 & -1.171 & .289 \\
\hline I recommend learning using blended classrooms. & 283 & 4.37 & 1.197 & -.286 & .145 & -1.113 & .289 \\
\hline $\begin{array}{l}\text { I recommend learning using the only face to face } \\
\text { lassrooms. }\end{array}$ & 283 & 4.08 & 1.213 & -.085 & .145 & -1.096 & .289 \\
\hline $\begin{array}{l}\text { The Google Hangouts used for online course } \\
\text { delivery was the most effective learning tool } \\
\text { platform. }\end{array}$ & 283 & 4.34 & 1.141 & -.282 & .145 & -.944 & .289 \\
\hline $\begin{array}{l}\text { The Google Classrooms used for online course } \\
\text { delivery was the most effective teaching platform. }\end{array}$ & 283 & 3.36 & 1.154 & -.299 & .145 & -1.004 & .289 \\
\hline $\begin{array}{l}\text { The quality material delivery used in LMS } \\
\text { (Moodle) was easy to use. }\end{array}$ & 283 & 3.34 & 1.150 & -.205 & .145 & -1.090 & .289 \\
\hline $\begin{array}{l}\text { The Zoom used for online course delivery was the } \\
\text { most effective teaching platform. }\end{array}$ & 283 & 3.13 & 1.096 & -.106 & .145 & -1.005 & .289 \\
\hline $\begin{array}{l}\text { The GoToMeeting used for online course delivery } \\
\text { was the most effective teaching platform. }\end{array}$ & 283 & 3.24 & 1.118 & -.063 & .145 & -.964 & .289 \\
\hline
\end{tabular}

While some students are satisfied with the employed online learning platforms, the complete shift of online platforms to deliver course activities, including lecture delivery, laboratory experiments, assessment, and student counseling, is not preferred. Their perceptions were justified because most of the students highly preferred the blended learning classrooms (AMS 4.37/Strongly Agree), where some topics can be covered online and few involving laboratories or critical concept support by face to face interaction on campus. The students mainly rated (AMS 3.11/Agree) to full courses to be taught online and (AMS 4.08/Strongly Agree) to the traditional face-to-face classroom environment. To answer the second research question: During COVID-19, what are the students' perceptions of the most effective employed online teaching platforms in their learning process? The students' perceptions of the most effective online learning methods and platforms are varied. The school has instructed the faculty and students to use Google Hangouts, Google Classroom mainly, and Moodle as LMS as the leading platforms; therefore, participants were more satisfied with Google Hangouts as a course delivery tool and Moodle for a medium of assessments and course portfolio management. It was observed that the students were just satisfied by the online learning platforms because most of the factors had an average mean score between 3 to 3.5 except the high significance of Google Hangouts (AMS 4.34/Strongly Agree). The students are content with the online classes and the tools used for lecture deliveries and assessments.

The Cronbach alpha value of the 8 questions of the last section of this study was (0.942), and the beforementioned measures validated the results of this section. 
The Cronbach alpha value of the 22 questions of this study was (0.95). A correlation assessment has been conducted for this study and was detected that there is a significant relationship between student satisfaction and online learning. It is not clear yet if the next semester in the higher education institutes would be purely online, mixed, or traditional face-to-face class lectures. Therefore, this correlation supports that student adoption to $100 \%$ online lecture would improve if adequate facilities and methods are provided, achieving the course learning outcomes. Table 6 shows the ANOVA and Correlations results.

Table 6. ANOVA and Correlation Results

\begin{tabular}{|c|c|c|c|c|c|c|}
\hline \multicolumn{7}{|c|}{ Model Summary ${ }^{\mathbf{b}}$} \\
\hline Model & $\boldsymbol{R}$ & R Square & \multicolumn{2}{|c|}{$\begin{array}{c}\text { Adjusted } R \\
\text { Square }\end{array}$} & \multicolumn{2}{|r|}{ Std. Error of the Estimate } \\
\hline 1 & $.198 \mathrm{a}$ & .039 & \multicolumn{2}{|c|}{.036} & \multicolumn{2}{|r|}{1.038} \\
\hline \multicolumn{7}{|c|}{ a. Predictors: (Constant), I recommend learning using ONLY online classes in the future. } \\
\hline \multicolumn{7}{|c|}{$\begin{array}{l}\text { b. Dependent Variable: I am satisfied with the online classes as they helped me achieve the course learning } \\
\text { outcomes. }\end{array}$} \\
\hline \multicolumn{7}{|c|}{ ANOVA $^{\mathrm{a}}$} \\
\hline & Model & $\begin{array}{l}\text { Sum of } \\
\text { Squares }\end{array}$ & $d f$ & $\begin{array}{l}\text { Mean } \\
\text { Square }\end{array}$ & $\boldsymbol{F}$ & Sig. \\
\hline \multirow{3}{*}{1} & Regression & 12.370 & 1 & 12.370 & 11.477 & $.001 \mathrm{~b}$ \\
\hline & Residual & 302.860 & 281 & 1.078 & & \\
\hline & Total & 315.230 & 282 & & & \\
\hline
\end{tabular}

a. Dependent Variable: I am satisfied with the online classes as they helped me achieve the course learning outcomes.

\begin{tabular}{|c|c|c|c|c|c|c|}
\hline \multicolumn{7}{|c|}{ b. Predictors: (Constant), I recommend learning using ONLY online classes in the future. } \\
\hline \multicolumn{7}{|c|}{ Coefficients $^{\mathbf{a}}$} \\
\hline \multirow{2}{*}{\multicolumn{2}{|c|}{ Model }} & \multicolumn{2}{|c|}{$\begin{array}{c}\text { Unstandardized } \\
\text { Coefficients }\end{array}$} & \multirow{2}{*}{\begin{tabular}{|c|}
$\begin{array}{c}\text { Standardized } \\
\text { Coefficients }\end{array}$ \\
Beta
\end{tabular}} & \multirow[t]{2}{*}{$t$} & \multirow[t]{2}{*}{ Sig. } \\
\hline & & $\boldsymbol{B}$ & Std. Error & & & \\
\hline & (Constant) & 3.375 & .167 & & 20.184 & .000 \\
\hline 1 & $\begin{array}{l}\text { I recommend learning } \\
\text { using ONLY online } \\
\text { classes in the future. }\end{array}$ & .169 & .050 & .198 & 3.388 & .001 \\
\hline
\end{tabular}

a. Dependent Variable: I am satisfied with the online classes as they helped me achieve the course learning outcomes.

This study concludes with a model for student satisfaction based on the collected data sample, as shown in Figure 1. 


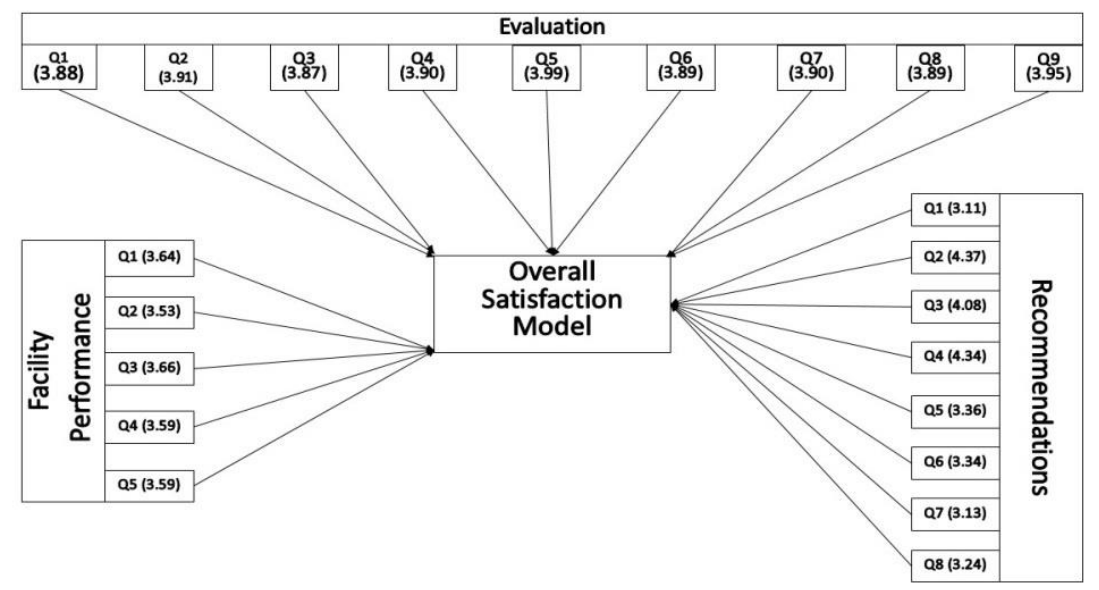

Fig. 1. Overall Satisfaction Model

This model presents the weights of each factor considered for this study, which are based on three key areas to analyze the overall student satisfaction, which includes Evaluation of the adopted practices by the instructor during online classes, Faculty Performance for the facilities provided by the institute, and Recommendations by the students to improve the gaps in online education rapidly adopted during COVID pandemic. Each factor weights out of the selected scale with a maximum value of 5 . This model assists the decision-makers to improve the features with lower values.

\section{Discussion}

Contrary to the findings of previous studies related to the Emergency Remote Teaching (ERT) during COVID-19, where students" reported challenges in course arrangements [41], drop out of their final grades [40], limited technical knowledge, and internet access [42], the result of this study designates that participants were satisfied with the school arrangement and faculty preparation to rapid shift face-to-face classrooms to online during the COVID-19 pandemic. In terms of online learning, the students' mean rankings progressively increased as the satisfaction of learning objectives, assessment plans, online platforms, webinars, and tutorials are high. Thus, this indicates that participants perceived the online learning platforms as experiential and constructive learning environments. Participants' high satisfaction level might be due to several reasons, including the level of support received from instructors (e.g., one to one feedback, inclusion in learning, understanding of specific circumstances), course's multimodal online delivery (e.g., audio, video, texts, PowerPoint slides, games, and quiz), instructors' guidance and follow-up (email, phone calls, and virtual meetings), the course level of engagement (e.g., active classroom vs. lecture-based), the instructors' various online teaching approaches (e.g., active learning opportunities, demonstrations, games, group, and individual discussion), the instructor's efforts in 
making the online learning personalized, and promotes a student-centered approach. The findings are in line with the tenets of transformative learning theories [19],[20],[1], which allows the learners to be authoritative and investors over their learning.

Further, the result indicated that the examined school successfully prepared a convenient and productive online learning environment. While learning in KSA's institutions is mainly based on the teacher-led classroom [5],[6],[7], participants in the study revealed positive attitudes toward experiential learning, which should be taken into consideration for future teaching implications. In this study, learners are reflecting on their learning through experience, which involved past acquainted knowledge of online learning platforms and technology use.

These results go beyond previous reports, showing that the COVID-19 pandemic led to a positive effect on students' overall gratification level of the employed alternative online platforms. An e-open book exam, oral exam, case studies, assignments, and project presentation were favorably reported assessment approaches in online learning. Because assessment plays a vital part in teaching and learning, allowing room for alternative assessment plans might play a considerable role in learner satisfaction levels, anxiety levels, and course outcomes. It is also suggested to use the Universal Design for Learning (UDL) for customizing learning assessments. UDL principles target learning environments that are adaptable, inclusive, and student-oriented to ensure that all students can acquire and acquire from the course materials [52]. While most participants were highly satisfied with the alternate assessment, it is also critical to measure and reevaluate assigned assessments in terms of validity, applicability, and effectiveness compared to close book exams and quizzes in face-to-face classrooms. Overall, these results are the following findings reported by [43] in which they reported a positive influence on students' performance in higher education during the COVID19 pandemic. Even though the KSA online system is not thoroughly fostered and reinforced [5],[6],[7],[53], the results were unexpectedly enlightening as learners aim to be agentive knowledge seekers who choose to be included in the learning process where they can assess, critique, and edit their work through the advantage of peer assessment in collaborative and constructive feedback [25],[26],[27]. Most students highly preferred blended learning classrooms rather than fully online courses and traditional face-to-face classroom environment.

Furthermore, the schools' webinars, seminars, and online courses offered during online teaching were favorably reported by the students as aides to their overall management in learning and skill development during online learning. Even though the school has instructed the faculty and students to mainly use Google Hangouts, Google Classroom, and Moodle as the leading platforms, participants were more satisfied with Google Hangouts as a course delivery tool and Moodle for a medium of assessments and course portfolio management. Thus, positively reported technical tools should be fully supported and prompted for future instruction within KSA institutions and elsewhere. 


\section{Conclusion}

Due to the spread of COVID-19, all sectors in the KSA, including the education sector, have prepared emergency and exit contingency plans to manage and overcome this unexpected epidemic. The institution in KSA and faculty members made numerous efforts to teach online and provide the students with the best experience during the COVID-19 pandemic under the active guidance of the Ministry of Education (MoE), KSA. This study explored the effectiveness of these teaching and learning experiences through students' perceptions of the actions taken by instructors, staff members, and the institution during online teaching. This study concludes that the students are satisfied with the university staff and faculty members who created a unified vision after COVID-19 in which they agreed on specific platforms to use, grading system, assessment options, training workshops, and online technical support.

Students are also satisfied with the facilities provided by the university. Regarding their most effective online learning platforms, it is concluded that Google Hangouts is the most effective tool for lecture delivery after Google Classroom and LMS (Moodle). The students are delighted with multimodality in delivering online instruction (e.g., audio and video quality). In general, all the students are highly satisfied with online teaching during COVID-19 and the activity follow-ups by faculty members on Moodle, WhatsApp, a social media app for group communication, and emails. The study revealed that the students are content with the alternative assessment types. The prompt of assessment plans used by instructors favored students achieving course learning outcomes, knowledge, and skills, as seen in their responses. Projects, question-based queries, open-book exams, assignments, and e-presentations are reported to be effective assessment techniques. However, universities and faculty members should rethink assessment types and weights to determine the careful measurement of students' learning [6]. More importantly, a series of professional development workshops and practical training courses are needed to be conditioned for the continuation of online learning and teaching success [54].

Despite some reservations of this school in KSA to teach online in the future [5],[6],[7],[53], this study also suggests that the institutes in KSA and elsewhere should start remodeling the instructional design to offer online courses in upcoming semesters based on students' satisfaction levels and needs. This study also suggests that institutes should offer online, blended, and face-to-face classrooms to meet up with many students' perceptions and increase its enrollment rate locally and internationally. More importantly, the online environment has proven to have a mediation with self-efficacy and self-regulated learning [9]. Blended courses were rated the most preferable where, for example, lab courses can be offered on campus, and other courses can be taught online.

Since this study primarily reviewed the participants' insights into online teaching strategies in developing their learning, future studies are recommended to explore how to accommodate and implement innovative learning strategies to engage learners inside the EFL classrooms. Since this study concentrates on specific teaching platforms, Google Hangouts, Google Classroom, Zoom, GoToMeeting, and Moodle (LMS), further stress should also be placed on reviews that contribute specific guidance and 
learning strategies on online practical and technical tools in English education in the KSA classroom and outside of where language learning takes place. As discussed earlier, the present study showed vital data related to students' insights into the most effective online platforms and the extent of their satisfaction level of instructors, staff, and school support. Although the findings of this study seem promising, the data were provided by a specific context; hence it is possible that the results would be different in the case of a multi-context examination. Further, the examined school is rated as one of the country's best schools regarding accreditations and quality implementation. The medium instruction is English, and enrolled learners are from different nationalities with adequate English backgrounds (conditional per admission). Moreover, learners have experience using the online system (Moodle) for many years, and it is used as a mainstay for their study materials, group projects, assessments, and grade reports.

Because of this study's timely nature during the COVID-19 crisis of 2020, it was critical to conduct the research promptly; however, this study encountered some limitations that must be declared. One of the study's limitations is that the number of participants is limited in this study. Thus, a study within a more diverse context and a large population would be recommended. Further, the student sampling is based on a convenience sampling of conveniently accessible students to participate in the study. Therefore, a random approach in a broader context might add significance to future research. It would be quite useful to do a comparative case study to measure learners' perceptions and applications within the online environment through interviews and observations on a larger scale of participants in different contexts to strengthen the generalizability of this study's findings. This is critical, as the current study is limited to one institution and specific school regulations. Future investigations are essential to validate the conclusions drawn from this study to investigate teachers' and learners' attitudes and performances from public and private universities in the KSA. On this basis, it is difficult to arrive at any judgments or conclusions concerning teaching quality, learning effectiveness, or learning achievements. Thus, there is a need to examine further where varied instructional designs can positively or negatively impact instructors' and learners' satisfaction levels.

Future research can further elaborate on this study by exploring the attitudes, perceptions, and applications of online EFL learners and instructors concerning the use of new technologies in online teaching during and after the summer and fall semester of 2020. Collecting data on the benefits and challenges of online teaching and learning during the unexpected COVID-19 pandemic would also be appropriate for teachers and administrators who are endeavoring to design mitigation strategies for future crises. Additionally, a follow-up study could ascertain if instructors intend to implement any of their future face-to-face classes and used methodologies in light of their new practices using online teaching methods.

As we have argued elsewhere, although emergency remote teaching (ERT) is a temporary and an alternate delivery online due to the COVID-19 pandemic, it may be considered a promising aspect of officially integrating and generating online schools and programs. The success of these implications is associated with integrating innovative online techniques (e.g., short personalized video lectures, digital readings, interactive projects, discussion forums, and gamification review tools) that involve 
solutions and suggestions for interactive instruction in teaching and learning. Furthermore, looking closer into how the online content was delivered during this

COVID-19 crisis, to what extent this performance met each learner's expectations, and whether or not there is a consideration of students' diversity in personality characteristics (e.g., introvert versus extrovert), learning abilities, and technology accessibility [55]. These dimensions are a few of many critical ones in designing productive online learning environments.

\section{Acknowledgment}

The authors thank Prince Sultan University for supporting this research project in affiliation with the Education Research Lab (ERL). The authors are also grateful for the IRB expedited review process and granting permission to complete this research.

\section{References}

[1] J. Mezirow, "Learning as Transformation: Critical Perspectives on a Theory in Progress. The Jossey-Bass Higher and Adult Education Series," no. Generic, p. 371, 2000.

[2] J. Wong et al., "Preparing for a COVID-19 pandemic: a review of operating room outbreak response measures in a large tertiary hospital in Singapore," Can. J. Anesth., 2020. https:// doi.org/10.1007/s12630-020-01620-9

[3] F. C. Bonafini, C. Chae, E. Park, and K. W. Jablokow, "How much does student engagement with videos and forums in a MOOC affect their achievement?," Online Learn. J. vol. 21, no. 4, pp. 223-240, 2017. https://doi.org/10.24059/olj.v21i4.1270

[4] E. N. Whelan Ariza, "Professional Development and Online Technology," TESOL Encycl. English Lang. Teach, pp. 1-7, 2018. https://doi.org/10.1002/9781118784235.eelt0900

[5] S. Al-Sharhan, A. Al-Hunaiyyan, R. Alhajri, and N. Al-Huwail, "Utilization of Learning Management System (LMS) Among Instructors and Students," Lect. Notes Electr. Eng., vol. 619, pp. 15-23, 2020. https://doi.org/10.1007/978-981-15-1289-6_2

[6] A. Alenezi, "The role of e-learning materials in enhancing teaching and learning behaviors," Int. J. Inf. Educ. Technol., vol. 10, no. 1, pp. 48-56, 2020.

[7] A. K. Hamdan, "The reciprocal and correlative relationship between learning culture and online education: A case from Saudi Arabia," Int. Rev. Res. Open Distance Learn., vol. 15, no. 1, pp. 309-336, 2014. https://doi.org/10.19173/irrodl.v15i1.1408

[8] Abdul Hafeez Muhammad, Asadullah Shaikh, Q. N. Naveed, and M. R. N. Qureshi, "Factors affecting academic Integrity in E-Learning of Saudi Arabian Universities. an Investigation Using Delphi and aHP," IEEE Access, vol. 8, pp. 16259-16268, 2020. https ://doi.org/10.1109/access.2020.2967499

[9] H. Algahtani, B. Shirah, A. Subahi, A. Aldarmahi, S. N. Ahmed, and M. A. Khan, "Perception of Students about E-learning: A Single-center Experience from Saudi Arabia," Dr. Sulaiman Al Habib Med. J., 2020. https://doi.org/10.2991/dsahmj.k.200327.001

[10] [A. O. A. \&Yusri B. K. Waleed Mugahed Al-Rahmi, Noraffandy Yahaya, Uthman Alturki, Amen Arabia, Ahmed A. Aldraiweesh, "Social media - based collaborative learning: the effect on learning success with the moderating role of cyberstalking and cyberbullying," J. Interact. Learn. Environ, 2020. https://doi.org/10.1080/10494820.2020.1728342

[11] D. S. Stein, "Keeping the Promise of Distance Education: Ethical Challenges for Higher Education Administrators," in Handbook of Research on Ethical Challenges in Higher 
Paper-Students' Satisfaction with Online Learning Experiences during the COVID-19 Pandemic

Education Leadership and Administration, 2020, p. 15. https://doi.org/10.4018/978-1-799 $\underline{8-4141-8 . \operatorname{ch} 015}$

[12] K. R. Prashanti Eachempati, "Ten maxims for out of class learning to outclass the academic challenges of COVID-19," MedEdPublish, 2020. https://doi.org/10.15694/mep. 2020.000089.1

[13] C. Cochran and L. Benuto, "Faculty transitions to online instruction: A qualitative case study," Online J. Distance Educ. e-Learning, vol. 4, no. 3, pp. 42-54, 2016.

[14] A. (University of V. Bakhtiar, "Regulating Self, Others' and Group Motivation in Online Collaboration," 2019.

[15] H. David Brecht, "Learning from Online Video Lectures," J. Inf. Technol. Educ. Innov. Pract., vol. 11, pp. 227-250, 2012.

[16] C. J. Brame, "Effective educational videos: Principles and guidelines for maximizing student learning from video content," CBE Life Sci. Educ., vol. 15, no. 4, p. es6.1-es6.6, 2016. https://doi.org/10.1187/cbe.16-03-0125

[17] B. Ahn and D. D. Bir, "Student interactions with online videos in a large hybrid mechanics of materials course," Adv. Eng. Educ., vol. 6, no. 3, pp. 1-24, 2018.

[18] W. Al-Ghaith, L. Sanzogni, and K. Sandhu, "Factors Influencing the Adoption and Usage of Online Services in Saudi Arabia," Electron. J. Inf. Syst. Dev. Ctries., vol. 40, no. 1, pp. 1-32, 2010. https://doi.org/10.1002/j.1681-4835.2010.tb00283.x

[19] P. Freire, "Pedagogy of the oppressed," Soc. Work A Read., pp. 114-120, 2013.

[20] T. M. Duffy and D. H. Jonassen, "Constructivism: New implications for instructional technology," Constr. Technol. Instr. A Conversat., pp. 1-16, 2013.

[21] J. Mezirow, "Transformative Dimensions of Adult Learning," JosseyBass High. adult Educ. Ser., p. 247, 1991.

[22] N. Almusharraf, "English as a foreign language learner autonomy in vocabulary development," J. Res. Innov. Teach. Learn, vol. 11, no. 2, pp. 159-177, 2018. https://doi. org/10.1108/jrit-09-2018-0022

[23] D. Kaufman, "Third generation course design in distance education," Postsecond. Distance Educ. Canada Policies Pract. Priorities, pp. 61-78, 1989. https://doi.org/10.1111/j.1365-27 29.1994.tb00293.x

[24] A. Kaye, "Computer-mediated communication and distance education," Mindweave Commun. Comput. distance Educ. (Oxford, Pergamon Press., pp. 3-21, 1989.

[25] K. McDonough, J. De Vleeschauwer, and W. J. Crawford, "Exploring the benefits of collaborative prewriting in a Thai EFL context," Lang. Teach. Res., vol. 23, no. 6, pp. 685701, 2019. https://doi.org/10.1177/1362168818773525

[26] Y. Su, Y. Li, J. C. Liang, and C. C. Tsai, "Moving literature circles into wiki-based environment: the role of online self-regulation in EFL learners' attitude toward collaborative learning," Comput. Assist. Lang. Learn., vol. 32, no. 5-6, pp. 556-586, 2019. https://doi.org/10.1080/09588221.2018.1527363

[27] K.-O. Jeong, "Online Collaborative Language Learning for Enhancing Learner Motivation and Classroom Engagement," Int. J. Contents, vol. 15, no. 4, pp. 89-96, 2019.

[28] L. Lee, "Synchronous online exchanges: A study of modification devices on non-native discourse," System, vol. 30, no. 3, pp. 275-288, 2002. https://doi.org/10.1016/s0346-251x $\underline{(02) 00015-5}$

[29] R. Adams, "Do second language learners benefit from interacting with each other?," Conversational Interact. Second Lang. Acquis., pp. 29-51, 2007.

[30] M. Laal and M. Laal, "Collaborative learning: What is it?," Procedia - Soc. Behav. Sci., vol. 31, pp. 491-495, 2012. https://doi.org/10.1016/j.sbspro.2011.12.092

[31] A. Klašnja-Milićević, B. Vesin, M. Ivanović, and Z. Budimac, "E-Learning personalization based on hybrid recommendation strategy and learning style identification," Comput. Educ., vol.56, no. 3, pp. 885-899, 2011. https://doi.org/10.1016/j.compedu.2010.11.001 
[32] T. C. Hsu, "Learning English with Augmented Reality: Do learning styles matter?," Comput. Educ., vol. 106, pp. 137-149, 2017. https://doi.org/10.1016/j.compedu.2016.12. $\underline{007}$

[33] C. M. Chen and C. H. Wu, "Effects of different video lecture types on sustained attention, emotion, cognitive load, and learning performance," Comput. Educ., vol. 80, pp. 108-121, 2015. https://doi.org/10.1016/j.compedu.2014.08.015

[34] Imelda, B. Y. Cahyono, and U. P. Astuti, "Effect of process writing approach combined with video-based mobile learning on Indonesian EFL learners' writing skill across creativity levels," Int. J. Instr., vol. 12, no. 3, pp. 325-340, 2019. https://doi.org/10.29333/ iji.2019.12320a

[35] A. Mohammadian, A. Saed, and Y. Shahi, "The Effect of Using Video Technology on Improving Reading Comprehension of Iranian Intermediate EFL Learners," Adv. Lang. Lit. Stud., vol. 9, no. 2, p. 17, 2018. https://doi.org/10.7575/aiac.alls.v.9n.2p.17

[36] H. Al Fadda, "The Relationship Between Self-Regulations and Online Learning in an ESL Blended Learning Context," English Lang. Teach., vol. 12, no. 6, p. 87, 2019. https://doi. org/10.5539/elt.v12n6p87

[37] S. S. Binyamin, M. J. Rutter, and S. Smith, "Extending the technology acceptance model to understand students' use of learning management systems in Saudi higher education," Int. J. Emerg. Technol. Learn., vol. 14, no. 3, pp. 4-21, 2019. https://doi.org/10.3991/ijet.v $14 \mathrm{i} 03.9732$

[38] M. Baig, Z. J. Gazzaz, and M. Farouq, "Blended learning: The impact of blackboard formative assessment on the final marks and students' perception of its effectiveness," Pakistan J. Med. Sci., vol. 36, no. 3, 2020. https://doi.org/10.12669/pjms.36.3.1925

[39] H. A. Rothan and S. N. Byrareddy, "The epidemiology and pathogenesis of coronavirus disease (COVID-19) outbreak," J. Autoimmun., vol. 109, 2020. https://doi.org/10.1016/j. jaut.2020.102433

[40] E. J. Sintema, "Effect of COVID-19 on the Performance of Grade 12 Students: Implications for STEM Education," Eurasia J. Math. Sci. Technol. Educ., vol. 16, no. 7, 2020. https://doi.org/10.29333/ejmste/7893

[41] D. Ivanov, "Predicting the impacts of epidemic outbreaks on global supply chains: A simulation-based analysis on the coronavirus outbreak (COVID-19/SARS-CoV-2) case," Transp. Res. Part E Logist. Transp. Rev., vol. 136, 2020. https://doi.org/10.1016/j.tre.20 $\underline{20.101922}$

[42] C. Owusu-Fordjour, C. K. Koomson, and D. \& Hanson, "The impact of COVID-19 on learning-the perspective of the Ghanaian student.,” Eur. J. Educ. Stud., vol. 7, no. 3, pp. 88101, 2020. http://doi:10.5281/zenodo.3753586

[43] T. Gonzalez et al., "Influence of COVID-19 confinement in students' performance in higher education," 2020

[44] M. Litwin, "How to Measure Survey Reliability and Validity," How to Meas. Surv. Reliab. Validity, 2014.

[45] M. H. N. Kausar, "The Correlation Between Presence And Average Means Score In Intermediate Of Mathematics Class," Pakistan J. Soc. Educ. Lang., vol. 4, no. 2, pp. 14-27, 2018.

[46] H. Liao, X. Wu, A. Keikha, and A. Hafezalkotob, "Power average-based score function and extension rule of hesitant fuzzy set and the hesitant power average operators," J. Intell. Fuzzy Syst., vol. 35, no. 3, pp. 3873-3882, 2018. https://doi.org/10.3233/jifs-18794

[47] N. A. R. Kesavan, "Consumers' Awareness On Packaged Drinking Water Brands In Ramnad District - Likert Mean Score Analysis," Int. J. World Res., vol. I, no. XXXIV, pp. 24-32, 2016.

[48] P. Barde and M. Barde, "What to use to express the variability of data: Standard deviation or standard error of mean?” Perspect. Clin. Res., vol. 3, no. 3, p. 113, 2012. https://doi. org/10.4103/2229-3485.100662 
[49] H.-Y. Kim, "Statistical notes for clinical researchers: assessing normal distribution (2) using skewness and kurtosis," Restor. Dent. Endod, vol. 38, no. 1, p. 52, 2013. https://doi. org/10.5395/rde.2013.38.1.52

[50] J. J. Vaske, J. Beaman, and C. C. Sponarski, "Rethinking Internal Consistency in Cronbach's Alpha," Leis. Sci., vol. 39, no. 2, pp. 163-173, 2017. https://doi.org/10.1080/0 1490400.2015 .1127189

[51] I. Trizano-Hermosilla and J. M. Alvarado, "Best alternatives to Cronbach's alpha reliability in realistic conditions: Congeneric and asymmetrical measurements," Front. Psychol., vol. 7, no. MAY, 2016. https://doi.org/10.3389/fpsyg.2016.00769

[52] K. A. Zhang, L., Basham, J. D., \& Lowrey, Foundations for Reinventing the Global Education System: Personalized Learning Supported Through Universal Design for Learning. 2020. https://doi.org/10.4018/978-1-5225-9775-9.ch008

[53] R. Garrett, "Whatever Happened to the Promise of Online Learning?," Int. High. Educ., no. 97, pp. 2-4, 2019.

[54] K. Al-Seghayer, "The actuality, inefficiency, and needs of EFL teacher-preparation programs in Saudi Arabia,” Int. J. Appl. Linguist. English Lit., vol. 3, no. 1, pp. 143-151, 2014. http://www.journals.aiac.org.au/index.php/IJALEL/article/view/1035. https://doi. org/10.7575/aiac.ijalel.v.3n.1p.143

[55] [S. Chesser, W. Murrah, and S. A. Forbes, "Impact of Personality on Choice of Instructional Delivery and Students' Performance," Am. J. Distance Educ., 2020. https:// doi.org/10.1080/08923647.2019.1705116

\section{Authors}

Norah Mansour Almusharraf is an assistant professor in the Department of Linguistics, Prince Sultan University, Riyadh, Saudi Arabia. Her professional and research interests focus on English as a foreign language (EFL) learning pedagogics, inquiry-based teaching and learning, cultural magnitudes of foreign/second language teaching and learning classroom, multimodal assessment and teaching strategies, technology implantation in the EFL English classrooms.

Shabir Hussain Khahro is an academician by profession currently working as an Associate Director of the Teaching and Learning Center, Prince Sultan University, Saudi Arabia. Mr. Khahro has more than 10 years of teaching and research experience in different countries. He has more than 50 publications of national and international repute, and his research interest areas are; Teaching Pedagogies, Effective Teaching, Project Management, Multi-Criteria Decision Making.

Article submitted 2020-05-19. Resubmitted 2020-07-07. Final acceptance 2020-07-08. Final version published as submitted by the authors. 


\section{Appendix A (Survey)}

\subsection{Items}

(1) Students' satisfaction level with the online learning environment

1.I am satisfied with the level of support received from instructors (e.g., one to one feedback, inclusion in learning, understanding of specific circumstances) during the COVID-19

2.I am satisfied with faculty members' alternative assessment plans during the COVID-19. (open book exam, oral exam, project, case study, presentation, or assignments).

3.I am satisfied with the course's multimodal online delivery (e.g., audio, video, texts, PowerPoint slides, games, and quiz).

4.I am satisfied with the online classes as they helped me achieve the course learning outcomes.

5. I am satisfied with the instructors' guidance and follow-up (email, phone calls, and virtual meetings) during online course activities.

6.I am satisfied with the gained knowledge and skills (e.g., analytical and research skills, flexibility, adaptability, interpersonal abilities) During Covid-19 Online Teaching.

7.I am Satisfied with the course level of engagement (e.g., active classroom vs. lecture-based) during online teaching.

8.I am satisfied with the instructors' various online teaching approaches (e.g., active learning opportunities, demonstrations, games, group, and individual discussion).

9.I am satisfied with how the instructor makes online learning personalized and promotes a studentcentered approach.

(2) Students' satisfaction of the school support during COVID -19

1. I am satisfied with staff responsiveness to technical support (e.g., account login, LMS support, Internet Technology Center) during the COVID-19.

2.I am satisfied with the school counselor's mental or social support.

3.I am satisfied with my academic advisor's follow up and support.

4.I am satisfied with the offered webinars, seminars, and extracurricular activities.

5.I am satisfied with the school provided facilities (e.g., tutorials, tutoring center, e-learning center, mentors).

\section{(3) Students perceptions of the most effective online learning methods and platforms}

1.I recommend learning using ONLY online classes in the future.

2.I recommend learning using blended classrooms (combines online educational interactive materials with face-to-face classroom methods).

3.I recommend learning using only face to face classrooms.

4. The Google Hangouts used for online course delivery was the most effective learning tool platform.

5.The Google Classrooms used for online course delivery was the most effective teaching platform.

6.The quality material delivery used in LMS (Moodle) was easy to use (e.g., no technical or content issues).

7.The Zoom used for online course delivery was the most effective teaching platform.

8.The GoToMeeting used for online course delivery was the most effective teaching platform. 